\section{Idowu Daniel Onisanwa}

(iD) https://orcid.org/0000-0002-5751-9984

Department of Economics

and Development Studies

Faculty of Humanities, Management

\& Social Sciences

Federal University, Kashere, Nigeria

onidan@yahoo.com

\section{Mercy Ojochegbe Adaji}

D https://orcid.org/0000-0002-0021-6827

Department of Economics

Faculty of the Social Sciences

University of Ibadan, Nigeria

msmercyadaji@gmail.com

\title{
Electricity consumption and its determinants in Nigeria
}

Accepted by Editor Ewa Ziemba | Received: June 29, 2019 | Revised: January 31, 2020; February 16, 2020 | Accepted: February 24, 2020.

\begin{abstract}
Aim/purpose - Low and fluctuating income coupled with epileptic supply of electricity and rising demand for electricity make determinants of electricity consumption an important issue in developing economies such as Nigeria; given that electricity is essential for the development of any economy. This paper, therefore, examines the determinants of electricity consumption in Nigeria with emphasis on income per capita, number of electricity customers, and electricity distribution shortages.

Design/methodology/approach - The study is anchored on the Utility Maximising Behaviour of consumers given their level of income. Data were sourced from the Energy Information Administration (EIA) database and World Development Indicator, 2018. An Autoregressive Distributed Lag (ARDL) technique was used in estimating the factors influencing electricity consumption in Nigeria over the period between 1981 and 2017.

Findings - The result reveals that the major propellers of electricity consumption in the long-run in Nigeria are per capita income, population per square kilometre, number of electricity customers as well as electricity shortages. The result refutes the hypothesis that electricity consumption increases with the rising level of income. Electricity consumption increased with the increasing number of population in a given area and the number of electricity customers, while electricity shortages distribution has a differential effect in the short run and long run.

Research implications/limitations - Lack of reliable household level data capturing per unit price of electricity, and other determinants of electricity consumption in Nigeria implies the analysis is to be carried out on the macro level. A micro-level analysis will be more beneficial in arriving at clearer estimates of demand for electricity in Nigeria.
\end{abstract}


Similarly, there are other factors that influence demand for electricity in Nigeria which are not readily available, hence the need to interpret the result with caveat.

Originality/value/contribution - The research focused on the determinants of electricity consumption instead of energy that has been extensively researched. It contributed to the existing literature on the determinants of electricity consumption in Nigeria by including electricity distribution shortages, number of electricity customers, and population per square kilometre.

Keywords: electricity consumption, electricity shortages, per capita income, Nigeria. JEL Classification: Q31, Q42.

\section{Introduction}

The economies of the world are overwhelmingly energy-dependent, and the Nigerian situation is not a different one. Electricity has been one of the major forms of energy; its importance cannot be overemphasised given the essential role it plays in the economic development of any country. Over the past few decades, electricity has become an essential tool of technological innovation and advancement. Human development will be impaired without access to electricity, given that basic household activities are carried out with the aid of electricity (OECD/IEA, 2016; Tully, 2006). There must be access to electricity for any meaningful development opportunity in this era. Electricity supports education by facilitating research; the vehicle through which economic ideas are transformed into profitable ventures.

In addition, access to electricity is the linkage between Africa and the Global economy grid (Latham \& Watkins Africa Practice, 2016). According to Krizanic (2007), standard of living in real term is a function of access to electricity. It is an indispensable source of food that is required for human survival across the globe. Therefore, access to electricity is a catalyst for the growth and development of an economy. Nevertheless, despite being fully aware of the role of energy in the economy and blessed with abundant energy sources, such as coal, oil, gas, hydropower and other renewable energy sources, Nigeria still faces a serious problem of energy poverty.

Particularly, the Power Africa Summit 2017 reported that fifty-five per cent of Nigerians lack access to electricity, while the forty-five per cent connected, suffers constantly from power failure. The estimated yearly electricity usage per capita in Nigeria was about $150 \mathrm{kWh}$; one of the lowest in Africa. In the same vein, only 3500-5000 MW of the $12.5 \mathrm{GW}$ installed generation capacity, is typically accessible (United States Agency for International Development [USAID], 
2017). One (2006) reported that the increasing demand for electricity has outgrown its supply and the rate of new connections is lower than the rate of new household formation due to population growth.

It is no doubt that the lack of access to electricity remains one of the biggest challenges to the development of Nigeria. Many people who do not have access to electricity are living in extreme poverty and use toxic, harmful and unsustainable energy sources for illumination, cooking. In 2012, the International Research Centre for Energy and Economic Development (ICEED) stated that about $72 \%$ of the Nigerian population are still depending on firewood for cooking; utilising the traditional 'three stone fires'. This has contributed to the indiscriminate felling of trees and its attendant environmental degradation and increasing desertification (Babanyara, Usman, \& Saleh, 2010). This was further corroborated by the World Bank estimate of an average annual deforestation rate of 4.12 per cent between 2000 and 2015 in the country.

Consequently, it has resulted in increased impoverishment, health diseases, poor access to social services, dampened women prospect, and hampered sustainability of the environment at local, national and global levels (Legros et al., 2009). According to (Carvallo, Shaw, Avila, \& Kammen, 2017), the incessant power outage has impaired the growth of sub-Sahara's economy and frustrated her efforts of actualising several development goals. Thus, the electricity crisis in Nigeria threatens to weaken regional and global market competition, obstruct job creation and reduce the rate of growth of the economy.

Therefore, it is important that the government and policy makers address the access to electricity crisis in the country if sustainable development is to be ascertained. Given that several efforts aimed at raising the supply of electricity by the government are not yielding the desire output calls for policy makers to be abreast with the factors that determines electricity supply (Ubi, Effiom, Okon, \& Oduneka, 2012). However, studies that determine access to electricity in Nigeria are scarcely investigated, as most studies focus majorly on the association between electricity and economic growth.

This research work extends a relatively new literature by examining the determinants of access to electricity in Nigeria with the use of a robust and quantitative research method on times series data that spans from 1981 to 2017. Specifically, the study seeks to determine the factors that influence electricity access and the relationship that exists between these factors and electricity access in Nigeria. 
The research paper is structured in five sections: the introduction, review of related literature, theoretical framework and research methodology, result and discussion of findings and summary of the findings, recommendations, conclusions and limitations encountered in the course of the study.

\section{Literature review}

The Energy Ladder Theory is the main theory that explains the household demands for electricity (Van der Kroon, Brouwer, \& van Beukering, 2013). The theory proposes that households maximise utility by making the most of a better source of energy given their income. Extensive empirical evidence is identified on factors that influence the demand for electricity using micro and macro level data. Their findings revealed that demand for electricity was associated with varying factors.

Review on studies for developed countries by Kavousian, Rajagopal, \& Fischer (2013) investigated the impacts of external conditions, physical characteristics of residential area, the number of occupants and the quantity of appliance and stock of electronics in the United States. The study found that external conditions, such as weather, physical state of the building, are the major determinants of residential consumption of electricity relative to other factors. Laicāne, Blumberga, Rošā, \& Blumberga (2014) analysed the determinants of electricity consumption in Latvia. The study examined factors, such as individual preference, socio-economy, assets endowment, demographic and external factors related to residential area and weather condition. The results revealed a high level of correlation among the determinants and electricity consumption. Lastly, for China Liu, Gao, Hao, \& Liao (2016) examined the association between residential electricity consumption and income. The result showed that household income is a major determinant of electricity consumption in China and a direct relationship between the growth of household income and demand for electricity was established. Considering developing countries, Khattak, Tariq, $\&$ Khan (2010) investigated the determinants of residential electricity consumption in Pakistan. The study showed that income, education attainment, prevailing weather conditions and number of rooms are the main determinants of household demand for electricity. The study revealed that the demand for electricity by a low income household was greatly influenced by price of electricity. Still for Pakistan, Zaman, Khan, Ahmad, \& Rustam (2012) stated that income, foreign direct investment and population growth have varying degree of positive influ- 
ence on the electricity consumption of residents and Zaman, Shaheen, Haider, \& Qamar (2015) identified the number of consumers, economic growth, price of electricity and electricity shortages as major influencers of electricity demand.

In addition, Kwakwa (2017) focusing on Egypt stated that the development of financial institutions, income, trade and education are the major determinants of increased demand for electricity in the country and Al-Bajjali \& Shamayleh (2018) revealed that economic growth, overall demand for water and industrialisation positively influenced the demand for electricity in Jordan.

Furthermore, studies have also been done for countries in the Sub-Saharan Africa. For example, Iniwasikima \& Ufot (2013) considered all countries in Sub-Saharan Africa and found that the percentage of rural dwellers, non-working population, population density, per capita income, savings and sincerity of the government are the key determinants of access to electricity. Specifically, for Ghana, Adam, Brew-Hammond, \& Essandoh (2013) found that the country's demand for energy is determined by the income levels among households. For instance, low-income households tend to use fire wood for cooking, while the use of electricity increases as income level rises. Inglesi-Lotz \& Pouris (2016) considered economic output or income as significant factors that influence electricity demand in South Africa. Kwakwa (2018) stated that urbanisation, population growth and industrialisation significantly account for the increase in demand for electricity in Benin. Sarkodie \& Adom (2018) found that price, urbanisation, and population density enhance demand and rising income level and climate change dampen electricity consumption in Kenya.

For Nigeria, Ekpo, Chuku, \& Effiong (2011) examined the dynamic of electricity consumption and attribute it to income, population size and industrialisation, while price of electricity is not significant in explaining its consumption. Ubi et al. (2012) found that technical know-how, government funding, and power loss were the major determinants of electricity consumption. Ubani (2013) considered urbanisation and level of unemployment are other factors in addition to household earnings, industrialisation and population growth that determine household electricity consumption. Usman (2013) found that a high proportion of electricity consumers were not contented with the services rendered by the electricity distribution companies, thereby constraining access to electricity. Ngutsav \& Aor (2014) using vector error correction approach, found that population, earnings, and industrialisation were the main drivers of electricity consumption. Ebere, Rufai, Okedina, \& Afodu (2018) revealed that number of households, number of manufacturing industry and population density are the major determinants of electricity in the country. 
The reviewed literature revealed that the demand for electricity is influenced by economic and non-economic factors. From the empirical studies, particularly those in developing countries, the dominant measure of determinants of consumption of electricity are national income, electricity prices, and price of alternative energy. Others are population, urbanisation, and industrialisation.

The dominant econometric approach applied in the analysis of existing studies is the Ordinary Least Squares (OLS), for example, Ubani (2013) and Ubi et al. (2012). The OLS technique in this content, assumes that all variables are integrated of the same order without ascertaining the stationarity properties of the series. This restricts the viability of the estimated results and leads to bias and inaccurate inferences. To address this problem, some studies Ekpo et al. (2011) and Babatunde \& Shuaibu (2009) made use of the autoregressive distributive lag approach.

This study is different from the previous studies, in the sense that, it is not limited to residential usage of electricity but aggregates the residential and commercial demand for electricity in the economy. This study also advances knowledge by examining the influence of electricity shortages on the demand for electricity in Nigeria, and in the use of ARDL framework as an econometric technique.

\section{Research methodology}

\subsection{Theoretical framework}

This study is based on the utility maximising behaviour of consumers given their income. The theory proposes that households will demand for a better source of energy as they experience increases in income, thereby maximising their satisfaction. The structure of electricity distribution in Nigeria reveals that the electricity sector in Nigeria is bedevilled by inadequate infrastructural facilities and most of its consumption is in the urban area of the country.

In the electricity sector, consumers would be better-off with adequate electricity supply, and as such any incremental changes in electricity prices/tariff may not necessarily induce an equivalent increase in electricity consumption. Therefore, the prominent factors affecting electricity access include income, price, transmission and distribution losses, population and other institutional factors (Al-Bajjali \& Shamayleh, 2018; Kwakwa, 2017; Ngutsav \& Aor, 2014; Ubani, 2013). 
This can be expressed mathematically as

$$
E C O_{t}=\alpha+Z_{i t}^{\prime} \gamma+\varepsilon_{t}
$$

where:

$E C O_{t}-$ electricity consumption,

$\mathrm{Z}_{i t}^{\prime}-k$-vector of the explanatory variables,

$\gamma$ - parameters to be estimated,

$\alpha-$ a scalar representing the constant of the equation,

$\varepsilon_{t}$ - the white noise error.

\subsection{Methodology}

The determinant of access to electricity in Nigeria can be expressed as

$$
E C O_{t}=F\left(G D P P C_{t}, P O P D_{t}, E S H_{t}, C U S_{t}\right)
$$

Equation (2) states that electricity consumption in Nigeria at time $t$ is a function of real income per capita (GDPPC); measured at constant 2010 USD, population density (POPD); the number of people (population) per square kilometre of land area, electricity shortages (ESH); losses in transmission from its generation to distribution and pilferage inclusive and electricity customers (CUS); the percentage of the population with access to electricity. The absence of credible and acceptable electricity pricing template in Nigeria implies lack of uniform price, thus, this study fails to include the electricity price in the model.

In line with the theoretical argument above, an econometric estimable equation is specified in equation 3 as:

$$
E C O_{t}=\alpha+\alpha_{1} G_{P P P C}+\alpha_{2} P O P D_{t}+\alpha_{3} E_{S H}+\alpha_{4} C U S_{t}+\varepsilon_{t}
$$

The study utilises the cointegration technique developed by Pesaran \& Shin (1999) and Pesaran, Shin, \& Smith (2001). The study uses the ARDL estimator because it does not mandate all the data series under consideration to be of the same order of cointegration and accommodates regressors that are either of order $\mathrm{I}(0)$ or I(1).

The ARDL framework of equation 3 is expressed as:

$$
\begin{gathered}
\Delta E C O_{t}=\alpha_{0}+\sum_{i=1}^{\rho} \alpha_{1} \Delta E C O_{t-i}+\sum_{i=1}^{\rho} \alpha_{2} \Delta G D P P C_{t-i}+\sum_{i=1}^{\rho} \alpha_{3} \Delta P O P D_{t-i}+\sum_{i=1}^{\rho} \alpha_{4} \Delta E S H_{t-i}+\sum_{i=1}^{\rho} \alpha_{5} \Delta C U S_{t-i} \\
+\eta_{1} E C O_{t-i}+\eta_{2} G D P P C_{t-i}+\eta_{3} P O P D_{t-i}+\eta_{4} E S H_{t-1}+\eta_{5} C U S_{t-1}+\varepsilon_{t}
\end{gathered}
$$


The expression $\alpha_{1}$ to $\alpha_{5}$ on the right-hand side is the short-run dynamics of the variables, while the expression from $\eta_{1}$ to $\eta_{5}$ without the summation symbols represents the long-run relationship between the variables, $\alpha_{0}$ is the drift parameter and $\varepsilon_{t}$ is the white noise.

The null hypothesis in equation 4 is that there is no long-run relationship among the variables. That is; $H_{0}: \eta_{1}=+\eta_{2}=\eta_{3}=\eta_{4}=\eta_{5}=0$ while the alternative is $H_{1}: \alpha_{1} \neq 0, \alpha_{2} \neq 0, \alpha_{3} \neq 0, \alpha_{4} \neq 0, \alpha_{5} \neq 0$.

The computed $F$-statistics figure is compared with upper and lower critical figures which are determined by Pesaran et al. (2001). If the computed $F$-statistic figure is greater than the upper critical figure, then the null hypothesis of no cointegration cannot be accepted and vice versa. The long-run relationship will be estimated with the best ARDL model based on Akaike Information Criterion (AIC) and Schwarz Criterion (SC).

The error correction model (equation 5) is then estimated

$$
\begin{aligned}
\Delta E C O_{t}=\beta_{0} & +\sum_{i=1}^{\rho} \delta_{i} \Delta E C O_{t-i}+\sum_{i=1}^{\rho} \phi_{i} \Delta G D P P C_{t-i}+\sum_{i=1}^{\rho} \varphi_{i} \Delta P O P D_{t-i} \\
& +\sum_{i=1}^{\rho} \lambda_{i} \Delta E S H_{t-i}+\sum_{i=1}^{\rho} \omega_{i} \Delta C U S_{t-i}+\alpha E C M_{t-1}+v_{t}
\end{aligned}
$$

The error correction model result shows the speed at which the system reverses back to equilibrium in the long-run after a short-run disturbance. The goodness of fit of the model is established using several diagnostic tests. The tests examine the reliability of the estimated results by testing for the presence of serial correlation using Breusch-Godfrey LM Test, Normality and Heteroscedasticity associated with the chosen model using ARCH test. The study also tests for the stability of the coefficient of the regression using the cumulative (CUSUM) and cumulative sum of squares (CUSUMSQ). The models were estimated using EViews software package.

\subsection{Data}

Data for this study are sourced from Energy Information Administration (EIA, 2018) database, and World Bank database (2018). The GDP per capita, population density and number of customers were obtained from World Bank database, while electricity shortages were sourced from the EIA. The natural logarithms of the variables are stated for analysis and cover the period 1981 to 
2017. All the variables are expected to have a significant positive relationship with electricity consumption in Nigeria, with the exception of electricity shortages that are presumed to have a negative influence.

\section{Research findings}

\subsection{Descriptive statistics}

Descriptive statistics of the variables used in the model are presented in Table 1.

Table 1. Descriptive statistics

\begin{tabular}{|l|r|r|r|r|r|}
\hline \multicolumn{1}{|c|}{ Staistics } & \multicolumn{1}{c|}{ ECO } & \multicolumn{1}{c|}{ GDPPC } & \multicolumn{1}{c|}{ ESH } & \multicolumn{1}{c|}{ POPD } & \multicolumn{1}{c|}{ CUS } \\
\hline Mean & 2.411504 & 7.388835 & 3.234574 & 4.85236 & 7.836255 \\
\hline Median & 2.131797 & 7.263262 & 3.436343 & 4.850375 & 7.769801 \\
\hline Maximum & 3.22446 & 7.84897 & 3.897254 & 5.319156 & 8.667164 \\
\hline Minimum & 1.545433 & 7.048496 & 1.769071 & 4.390216 & 6.60665 \\
\hline Std. Dev. & 0.51167 & 0.267862 & 0.545773 & 0.277289 & 0.585752 \\
\hline Skewness & 0.225508 & 0.519743 & -1.069871 & 0.015309 & -0.170456 \\
\hline Kurtosis & 1.602664 & 1.678558 & 3.064521 & 1.821853 & 2.164938 \\
\hline Jarque-Bera & 3.323775 & 4.35789 & 7.064938 & 2.141324 & 1.254222 \\
\hline Probability & 0.18978 & 0.113161 & 0.029233 & 0.342782 & 0.534133 \\
\hline Sum & 89.22564 & 273.3869 & 119.6792 & 179.5373 & 289.9415 \\
\hline Sum Sq. Dev. & 9.425006 & 2.583002 & 10.72324 & 2.768017 & 12.35181 \\
\hline Observations & 37 & 37 & 37 & 37 & 37 \\
\hline
\end{tabular}

Source: Authors' computation using E-views 10.

The findings revealed that electricity consumption (ECO), electricity shortages ((ESH) and number of electricity consumers (CUS) recorded the highest variation, while rural population density (POPD) and GDP per capita (GDPPC) have relatively lower variability. Some variables recorded a positive skewness, which means that the distributions are tailed to the right, while electricity shortages and number of commercial users have a negative skewness.

\subsection{Stationarity (unit root) test}

The results of Augmented Dickey-Fuller (ADF) and Philips-Perron (PP) tests, showing the order of integration $\mathrm{I}(\mathrm{d})$ of the series are represented in Table 2. It shows that the series are either integrated of order zero; I (0) or integrated of order one; I (1). 
Table 2. Unit root tests results

\begin{tabular}{|c|c|c|c|c|}
\hline Statistics/Variable & $\mathrm{ADF}$ & $\mathrm{I}(\mathrm{d})$ & PP & $\mathrm{I}(\mathrm{d})$ \\
\hline $\begin{array}{l}\text { Electricity } \\
\text { consumption }\end{array}$ & $\begin{array}{r}-7.62012 * * * \text { a } \\
(0.0000)\end{array}$ & $\mathrm{I}(1)$ & $\begin{array}{r}-7.53086^{* * * a} \\
(0.0000)\end{array}$ & $\mathrm{I}(1)$ \\
\hline GDP per capita & $\begin{array}{r}-4.852191 * * * a \\
(0.0004)\end{array}$ & $\mathrm{I}(1)$ & $\begin{array}{r}-4.84882 * * * \\
(0.0004) \\
\end{array}$ & $\mathrm{I}(1)$ \\
\hline Electricity shortages & $\begin{array}{r}-8.713683^{* * * a} \\
(0.000)\end{array}$ & $\mathrm{I}(1)$ & $\begin{array}{r}-9.14011 * * * \\
(0.0000)\end{array}$ & $\mathrm{I}(1)$ \\
\hline Population density & $\begin{array}{r}-5.054706^{* * * b} \mathrm{~b} \\
(0.0018)\end{array}$ & $\mathrm{I}(0)$ & $\begin{array}{r}-3.31425^{* * * a} \text { a } \\
(0.0216)\end{array}$ & $\mathrm{I}(0)$ \\
\hline $\begin{array}{l}\text { Electricity } \\
\text { customers }\end{array}$ & $\begin{array}{r}-4.595113 * * * \mathrm{a} \\
(0.0008)\end{array}$ & $\mathrm{I}(1)$ & $\begin{array}{r}-4.58361^{* * * a \mathrm{a}} \\
(0.0008)\end{array}$ & $\mathrm{I}(1)$ \\
\hline
\end{tabular}

a Represents at intercept.

b Represents at intercept and trend and the optimal lag structure is determined by Schwarz information criterion.

Note: *, **and *** denote $10 \%, 5 \%$ and $1 \%$ significance level, respectively.

Source: Authors' compilation from EViews.

The stationarity test shows that all the variables are I(1), except population density that is stationary at level, hence, integrated of order zero; $\mathrm{I}(0)$.

\subsection{Testing for cointegration}

Following the theoretical framework and the direction of mixture of stationarity, which justified the use of the autoregressive distributed lag model. This study estimates the impact of factors identified in the literature as determinants of electricity consumption in Nigeria, also electricity shortages are included, given the epileptic nature of power supply in the country.

The bounds co-integration test for the effect of per capita income, population density, number of commercial consumers and electricity shortages on electricity consumption in Nigeria is reported in Table 3.

Table 3. Bounds test results

\begin{tabular}{|l|r|r|}
\hline \multicolumn{1}{|c|}{ Computed bounds } & \multicolumn{1}{|c|}{ F-Statistic } & \multicolumn{1}{c|}{ K } \\
\cline { 2 - 3 } & 4.84125 & Upper I(1): \\
\hline Bounds level & Lower I $(0):$ & 5.53 \\
\hline $1 \%$ critical bounds value & 4.09 & 4.01 \\
\hline $5 \%$ critical bounds value & 2.95 & 3.46 \\
\hline $10 \%$ critical bounds valu & 2.46 & \\
\hline
\end{tabular}

Source: Authors' computation using E-views 10. 
The calculated F-Statistics is greater than the upper bound values at 5\% and $10 \%$ level of significance. This result provides evidence of cointegration, hence, a long-run relationship among the variables is included in the equation. Hence the alternative hypothesis of cointegration cannot be rejected and long-run co-integration relationship is established among the variables in the model.

The ARDL results obtained from the empirical analysis of the effect of per capita income (GDPPC), population density (POPD), electricity shortages (ESH) and electricity customers (CUS) on electricity consumption (ECO) in Nigeria for the period 1981-2017 are reported in Table 4.

Table 4. ARDL regression results

\begin{tabular}{|c|c|c|c|}
\hline \multicolumn{2}{|c|}{ Long-run Results } & \multicolumn{2}{|c|}{ Short-run Results } \\
\hline Variable & Coefficient & Variable & Coefficient \\
\hline$G D P P C$ & $-1.2602(-2.0454)$ & $\triangle G D P P C$ & $0.6090(3.0868)$ \\
\hline$P O P D$ & $2.6092(5.3146)$ & $\triangle P O P D$ & 519.5955 (1.8076) \\
\hline ESH & $0.6427(4.3658)$ & $\Delta E S H$ & $-0.1357(-2.6027)$ \\
\hline CUS & $0.3849(1.4888)$ & $\triangle C U S$ & $0.7272(4.7814)$ \\
\hline & & $\operatorname{ECM}(-1)$ & $-0.8886(-6.17453)$ \\
\hline R-SQUARE & \multicolumn{3}{|l|}{0.7401} \\
\hline AdJ. R-SQUARE & \multicolumn{3}{|l|}{0.667} \\
\hline
\end{tabular}

Source: Authors' computation using E-views 10.

The long-run results suggest that the coefficient of per capita income, population density and electricity losses are statistically significant at different conventional significance level, though with varying sign. The findings reveal that the number of electricity customers, electricity shortages, and population per square kilometre are positively signed. However, only electricity shortages and population density are statistically significant in explaining electricity consumption. Meanwhile, income per capita exerts a statistically significant negative effect on electric power consumption in Nigeria.

Table 5. Results of the diagnostic test

\begin{tabular}{|l|r|}
\hline \multicolumn{1}{|c|}{ Test Statistics } & Probability \\
\hline Godfrey Serial Correlation LM Test & $(0.2153)$ \\
\hline Heteroskedasticity(ARCH) & $(0.3352)$ \\
\hline Linearity (Ramsey Reset) & $(0.4308)$ \\
\hline CUSUM Test & Stable \\
\hline
\end{tabular}

Source: Authors' computation using E-views 10. 
The post estimation diagnosis tests of the model are presented in Table 5. The Breusch-Godfrey LM test statistics has an approximate probability value of 0.2153 , which shows that the model is free of serial correlation issue. The ARCH Heteroskedasticity test with probability statistics of 0.3352 evidences the absence of heteroskedasticity in the chosen model, while the Ramsey RESET with a probability value is greater than 0.05 confirmed the linearity of the model. The cumulative sum (CUSUM) and CUSUM of square (CUSUMSQ) tests are shown in Figures 1 and 2.

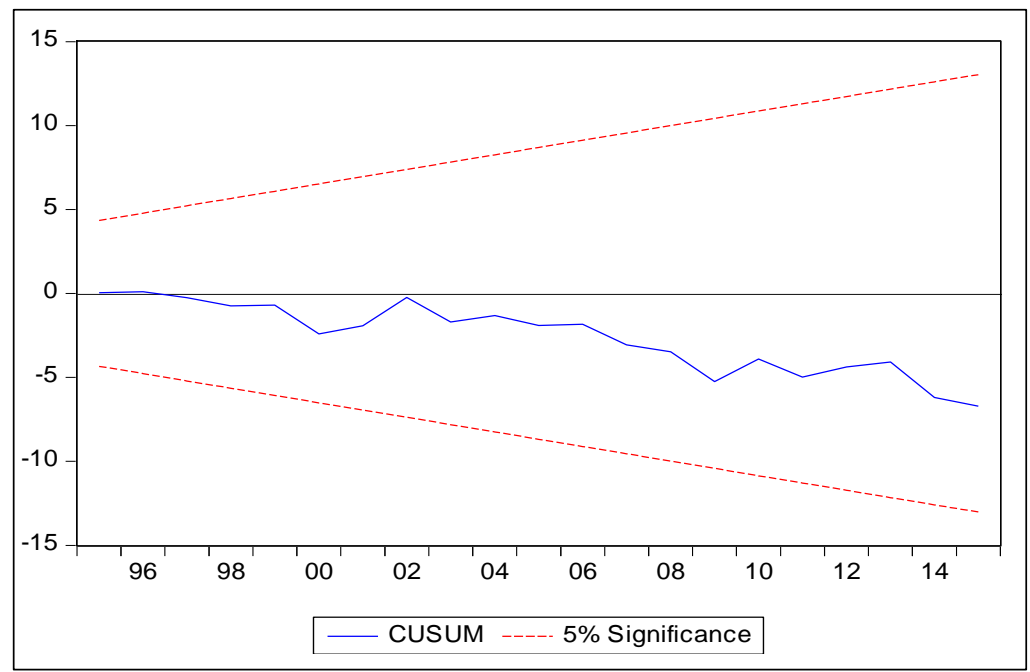

Figure 1. Stability test, recursive estimates CUSUM test

Source: Authors' computation.

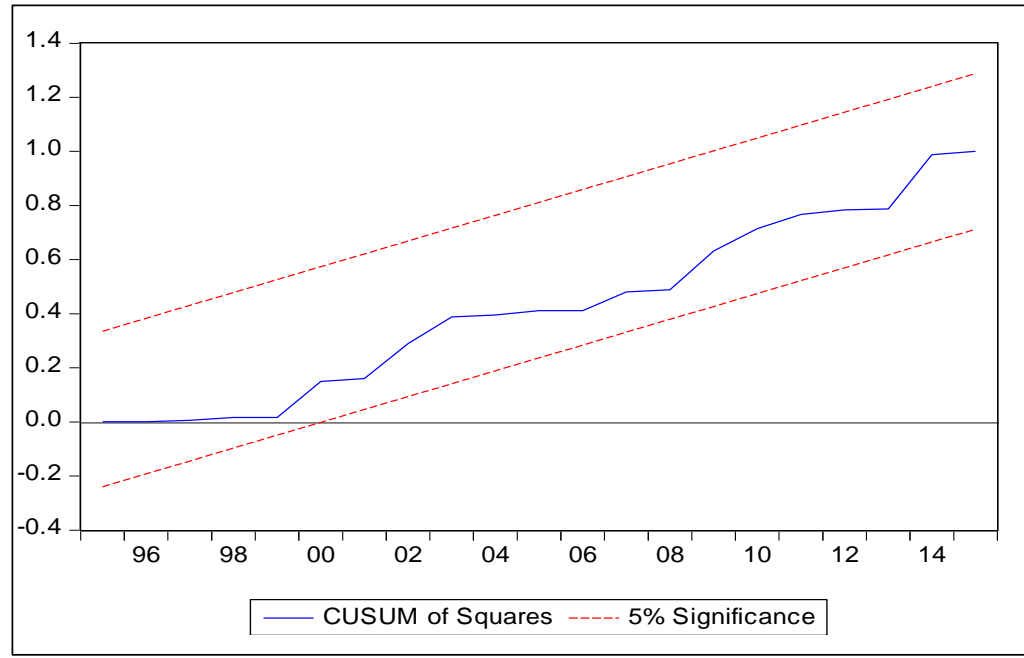

Figure 2. Stability test, recursive estimates CUSUM of squares test Source: Authors' computation. 
The tests in Figures 1 and 2 revealed that the long run coefficients are stable within the period covered.

\section{Discussion}

A rise in income per capita dampens the level of electric power consumption in the long run, while the number of population density raises the amount of electricity consumed in Nigeria. Contrary to expectation, electricity shortages in Nigeria show a positive relationship with consumption of electricity in the longrun. These results reveal that real per capita income, population density, and number of electricity customers are the major propellers of demand for electricity consumption in Nigeria in the long-run.

The sign of the coefficient of GDPPC tends to suggest that consumers switched to other alternative sources of energy, such as the use of inverter, solar panel, and generator as their income rises. This seems to make sense given the epileptic power supply across the country, coupled with indiscriminate high electricity tariff charged by the power distribution companies, thereby making public electricity providers a more costly source of energy. This finding is however, contrary to what was obtainable in most studies, for instance, Zaman et al. (2015) found a positive and significant relationship between GDP and consumption of electricity in Pakistan. Similarly, Khattak et al. (2010) and Adam et al. (2013) revealed that rising income level leads to increased usage of household electric appliances.

Further, the result is not in line with the outcome of some studies in Nigeria. Babatunde \& Shuaibu (2009) found a positive and significant income elasticity of demand for residential electricity consumption. The result of Ekpo et al. (2011) reveals a positive relationship between income and electricity consumption. These findings further give credence to the peculiarity of electricity consumption in Nigeria.

On the contrary, Ubani (2013) shows that income has a positive but insignificant effect on electricity consumption in Nigeria. Ngutsav \& Aor (2014) showed that household income is negatively related to the consumption of electricity in Nigeria.

According to results, population per square kilometre and number of electricity customers positively impacts the consumption of electricity in Nigeria. This shows that increase in the number of individual, household, and commercial clients tended to raise the consumption of electricity. These findings are consistent with the outcome of some studies in Nigeria, Babatunde \& Shuaibu 
(2009), Ubani (2013), and Ngutsav \& Aor (2014) who recorded a positive and significant relationship among population, number of electricity users, and access to electricity.

Electricity demands tend to fall with fallen level of electricity distribution in Nigeria. In the presence of electricity shortage, households with low per capita income utilise more expensive source of energy, such as the use of fuel-wood, charcoal among other non-environmental friendly sources of energy, therefore, a justification for the inverse relationship between electricity shortages and the consumption of electricity in Nigeria.

The short-run ARDL model showed that the main determinants of electricity consumption in Nigeria are income per capita, electricity shortages, number of electricity customers and population density. The findings revealed that income per capita, number of electricity customers and population density had positive impact on consumption of electricity in Nigeria. The findings reveal that increase in the number of electricity consumers and economic activities tend to spur electric power usage in Nigeria. Given the increase in demand associated with electricity shortages, it is imperative for government to make an impact assessment of electricity shortages on the economy in order to achieve sustainable economic development.

The error correction term (CointEq(-1)) is negative and statistically significant. This further established the existence of a long-run relationship among variables. The ECM is the speed of adjustment back to equilibrium after a disturbance in the dynamic model. The coefficient of the ECM is -0.889 , that is, a previous year's deviation from the long-run equilibrium is adjusted by approximately $89 \%$ after each disturbance within a year, other things remaining the same.

\section{Conclusions}

\subsection{Research contribution}

The research focused on the determinants of electricity consumption instead of energy that has been extensively researched. This study contributes to the existing literature on the determinants of electricity consumption in Nigeria by including electricity distribution shortages, number of electricity customers, and population per square kilometre. However, there are other factors, such as electricity own price, degree of urbanisation, price of alternative source of energy, among others, that influence demand for electricity in Nigeria which are not readily available, hence the need to interpret the results with caveat. 


\subsection{Research implication}

The results indicate that income per capita, electricity distribution shortages, number of electricity customers, and population density are the main determinants of electricity consumption in Nigeria. The findings reveal a long-run relationship between electricity consumption and its main determinants. Income per capita is negatively associated with electricity consumption, while electricity distribution shortages, number of electricity customers, and population per square kilometre exert a positive influence on demand for electric power in Nigeria.

In addition, the negative relationship between income per capita and electricity consumption suggests that increase in GDPPC can be used as a means of manipulating or adjusting electricity consumption in Nigeria and to ensure efficiency in the utilisation of electricity.

Furthermore, despite the epileptic power supply in Nigeria; resulting from electricity distribution shortages, the demand for electric power still remains high. This means there is a need for capacity installation to meet demand and an efficient electric power generation in Nigeria to boost economic activities. Thus, government should place emphasis on policies that increase employment, steady population growth, urban development and alternative sources of energy that are cost efficient and environmentally friendly to ensure adequate access to electricity.

\subsection{Research limitation and future works}

Further research is required to determine other factors (such as price of electricity) that influence the consumption of electricity in Nigeria. A major limitation of this study is lack of reliable household data capturing per unit price of electricity. However, the determinants of electricity consumption in a country such as Nigeria are better identified at the household level. An understanding of the determinant of electricity consumption at the micro-level can assist in electricity reforms through the provision of information on the structure of residential electricity consumption in Nigeria. 


\section{References}

Adam, F. W., Brew-Hammond, A., \& Essandoh, E. O. (2013). Relationships between energy use and income levels, for households in Ghana. European Scientific Journal, 9(16), 233-245. https://doi.org/10.19044/esj.2013.v9n16p\%25p

Al-Bajjali, S. K., \& Shamayleh, A. Y. (2018, March). Estimating the determinants of electricity consumption in Jordan. Energy, 147, 1311-1320. https://doi.org/10.1016 /j.energy.2018.01.010

Babanyara, Y. Y., Usman, H. A., \& Saleh, U. F. (2010). An overview of urban poverty and environmental problems in Nigeria. Journal of Human Ecology, 31(2), 135-143. https://doi.org/10.1080/09709274.2010.11906304

Babatunde, M. A., \& Shuaibu, M. I. (2009, August). The demand for residential electricity in Nigeria: A bound testing approach. In Proceedings of 2nd International Workshop on Empirical Methods in Energy Economics. Retrieved from http:// citeseerx.ist.psu.edu/viewdoc/download?doi=10.1.1.533.3845\&rep=rep1\&type=pdf

Carvallo, J. P., Shaw, B. J., Avila, N. I., \& Kammen, D. M. (2017). Sustainable low-carbon expansion for the power sector of an emerging economy: The case of Kenya. Environmental Science \& Technology, 51(17), 10232-10242. https://doi.org/10.1021/ acs.est.7b00345

Ebere, C., Rufai, A., Okedina, M., \& Afodu, J. (2018). The determinants of electricity demands in Nigeria from 1970-2016: Error correction mechanism approach. Journal of Resources Development and Management, 46(1), 23-33. Retrieved from http:// www.iosrjournals.org/iosr-jef/papers/Vol9-Issue4/Version-1/G0904015060.pdf

Ekpo, U. N., Chuku, C. A., \& Effiong, E. L. (2011). The dynamics of electricity demand and consumption in Nigeria: Application of the bounds testing approach. Current Research Journal of Economic Theory, 3(2), 43-52.

Energy Information Administration [EIA]. (2018). Retrieved from https://www. eia.gov/international/data/country/NGA/electricity/electricity-generation?pd=2\&p

Inglesi-Lotz, R., \& Pouris, A. (2016). On the causality and determinants of energy and electricity demand in South Africa: A review. Energy Sources, Part B: Economics, Planning, and Policy, 11(7), 626-636. https://doi.org/10.1080/15567249.2013. 801536

Iniwasikima, P., \& Ufot, C. (2013).The determinants of electricity access in Sub-Saharan Africa. The Empirical Econometrics and Quantitative Economics Letters, 2(4), 65-74.

Kavousian, A., Rajagopal, R., \& Fischer, M. (2013). Determinants of residential electricity consumption: Using smart meter data to examine the effect of climate, building characteristics, appliance stock, and occupants' behaviour. Energy, 55, 184-194. https://doi.org/10.1016/j.energy.2013.03.086

Khattak, N. U. R., Tariq, M., \& Khan, J. (2010). Determinants of household's demand for electricity in district Peshawar. European Journal of Social Sciences, 14(1), 7-16. Retrieved from https://mpra.ub.uni-muenchen.de/id/eprint/56007 
Krizanic, F. (2007). The European market of electricity and natural gas. Ljubljana: EIB Forum: Investing in Energy, Mastering Climate Change.

Van der Kroon, B., Brouwer, R., \& van Beukering, P. J. H. (2013). The energy ladder: Theoretical myth or empirical truth? Results from a meta-analysis. Renewable and Sustainable Energy Reviews, 20, 504-513. https://doi.org/10.1016/j.rser.2012. 11.045

Kwakwa, P. A. (2017). Electricity consumption in Egypt: A long-run analysis of its determinants. OPEC Energy Review, 41(1), 3-22. https://doi.org/10.1111/opec.12091

Kwakwa, P. A. (2018). Analysis of the determinants of electricity consumption in Benin. Journal of Energy Management and Technology, 2(3),42-59. https://doi.org/10. 22109/jemt.2018.125839.1075

Laicāne, I., Blumberga, A., Rošā, M., \& Blumberga, D. (2014). Determinants of household electricity consumption savings: A Latvian case study. Agronomy Research, 12(2), 527-542. Retrieved from http://citeseerx.ist.psu.edu/viewdoc/download? doi=10.1.1.895.5815\&rep=rep1\&type $=$ pdf

Latham \& Watkins Africa Practice. (2016). Nigerian power sector: Opportunities and challenges for investment in 2016 (Client Alert White Paper, No. 1930). Retrieved from https://www.lw.com/thoughtLeadership/lw-nigerian-power-sector-opps-andchallenges

Legros, G., Havet, I., Bruce, N., Bonjour, S., Rijal, K., Takada, M., \& Dora, C. (2009). The energy access situation in developing countries: a review focusing on the least developed countries and Sub-Saharan Africa. Geneva: World Health Organization.

Liu, Y., Gao, Y., Hao, Y., \& Liao, H. (2016). The relationship between residential electricity consumption and income: A piecewise linear model with panel data. Energies, 9(10), 831. https://doi.org/10.3390/en9100831

Ngutsav, A., \& Aor, R. (2014). Analysis of determinants of electricity consumption in Nigeria. The Nigerian Journal for Energy and Environmental Economics, 6(1). Retrieved from https://uchenwogwugwu.wordpress.com/2014/11/22/analysis-ofdeterminants-of-electricity-consumption-in-nigeria/

OECD/IEA. (2016). Energy and air pollution. World Energy Outlook Special Report. Paris: Author. Retrieved from https://webstore.iea.org/download/summary/343? fileName=English-WEO-Air-Pollution-ES.pdf

One, E. (2006). Rural electrification strategy and implementation plan of the federal republic of Nigeria prepared for the Power Sector Reform Team Bureau of Public Enterprises. Retrieved June 28, 2018 from http://rea.gov.ng/inc/uploads/2017/09/ RESIP. pdf

Pesaran, M. H., \& Shin, Y. (1999). An autoregressive distributed-lag modelling approach to cointegration analysis. Econometric Society Monographs, 31, 371-413.

Pesaran, M. H., Shin, Y., \& Smith, R. J. (2001). Bounds testing approaches to the analysis of level relationships. Journal of Applied Econometrics, 16(3), 289-326. https://doi.org/10.1002/jae.616 
Sarkodie, S. A., \& Adom, P. K. (2018, September). Determinants of energy consumption in Kenya: A NIPALS approach. Energy, 159, 696-705. https://doi.org/10.1016/ j.energy.2018.06.195

Tully, S. (2006). The human right to access electricity. The Electricity Journal, 19(3), 30-39. http://doi.org/10.1016/j.tej.2006.02.003

Ubani, O. (2013). Determinants of the dynamics of electricity consumption in Nigeria. OPEC Energy Review, 37(2), 149-161. https://doi.org/10.1111/opec.12004

Ubi, P. S., Effiom, L., Okon, E. O., \& Oduneka, A. E. (2012). An econometric analysis of the determinants of electricity supply in Nigeria. International Journal of Business Administration, 3(4), 72-82. https://doi.org/10.5430/ijba. v3n4p72

United States Agency for International Development [USAID]. (2017). Power Africa Fact Sheet. Retrieved from http://www.usaid.gov/powerafrica

Usman, A. (2013). Determinants of electricity consumers satisfaction in selected electricity distribution zones in Nigeria: Implications for regulatory activities. Journal of Asian Business Strategy, 3(6), 103. Retrieved from http://www.aessweb.com /pdf-files/1-74-JABS-3(6)2013,\%20103-124.pdf

World Bank. (2018). World Development Indicators. Retrieved from https://data catalog.worldbank.org/dataset/world-development-indicators

Zaman, K., Khan, M. M., Ahmad, M., \& Rustam, R. (2012, November). Determinants of electricity consumption function in Pakistan: Old wine in a new bottle. Energy Policy, 50, 623-634. https://doi.org/10.1016/j.enpol.2012.08.003

Zaman, M., Shaheen, F., Haider, A., \& Qamar, S. (2015). Examining relationship between electricity consumption and its major determinants in Pakistan. International Journal of Energy Economics and Policy, 5(4), 998-1009. Retrieved from https://www.econjournals.com/index.php/ijeep/article/download/1299/860 